\title{
Analisis Kelayakan Usaha Secara Finansial dan Efisiensi Produksi di Peternakan Sapi Perah PT. Fructi Agri Sejati Kabupaten Jombang
}

\author{
(ANALYSIS OF FINANCIAL BUSINESS FEASIBILITY AND PRODUCTION \\ EFFICIENCY IN DAIRY COW LIVESTOCK PT. FRUCTI AGRI SEJATI JOMBANG \\ REGENCY)
}

\author{
Khafsah $^{1 *}$, Sunaryo Hadi Warsito ${ }^{2}$, Ragil Angga Prastiya ${ }^{3}$, Trilas Sardjito ${ }^{3}$, Amung \\ Logam Saputro4, Bodhi Agustono \\ ${ }^{1}$ Bachelor of Veterinary Medicine, \\ ${ }^{2}$ Department of Animal Husbandry, \\ ${ }^{3}$ Department of Veterinary Reproduction, \\ ${ }^{4}$ Department of Clinic and Animal Hospital, \\ Faculty of Veterinary Medicine, Universitas Airlangga, \\ UNAIR C-Campus Mulyorejo, Surabaya, Jawa Timur, Indonesia, 60115 \\ Telp. (031)5993016, Fax. (031)5993015 \\ *Corresponding author: khafsah-2014@ @ fkh.unair.ac.id
}

\begin{abstract}
Abstrak
Penelitian ini bertujuan untuk mengetahui tentang analisis kelayakan usaha secara finansial dan efisiensi produksi peternakan sapi perah di PT. Fructi Agri Sejati Kabupaten Jombang yang mempunyai 100 ekor sapi Peranakan Fries Holland (PFH). Jenis penelitian deskriptif yang dilaksanakan di Dusun Komboh Desa Sambirejo Kecamatan Wonosalam Kabupaten Jombang. Penelitian menggunakan metode survey yang kemudian diperoleh data primer dan sekunder dari PT. Fructi Agri Sejati melalui wawancara dengan menggunakan kuesioner. Analisis kelayakan usaha berdasarkan kriteria kelayakan investasi meliputi Net Present Value (NPV), Net Benefit Cost Ratio (Net B/C), Internal Rate Return (IRR), Payback Periode (PP) dan R/C Ratio untuk analisis efisiensi produksi. Hasil penelitian menunjukkan besar pendapatan rata-rata per tahun sebesar Rp.141.669.425, dengan rata-rata penerimaan sebesar Rp.898.382.687 yang bersumber dari hasil penjualan susu, pedet jantan, sapi afkir, pejantan, sapi laktasi dan pupuk kandang. Berdasarkan hasil penelitian usaha layak untuk dijalankan karena semua kriteria investasi mampu dicapai, memiliki NPV>0 yaitu Rp.181.016.633, Net B/C>0 yaitu 1,15, IRR sebesar 12,3\% lebih besar dari tingkat diskonto yang digunakan dan PP selama 7,2 tahun. Efisiensi produksi dinyatakan sudah efisien karena nilai R/C >0 yaitu 1,18.
\end{abstract}

Kata kunci: analisis finansial, efisiensi produksi, PT. Fructi Agri Sejati, Kabupaten Jombang

\begin{abstract}
The research objectives are an analysis of financial feasibility and production efficiency of the dairy farm business in PT. Fructi Agri Sejati Jombang Regency which has 100 cattle Fries Holland Cross. The type of this research is descriptive research that was conducted in Wonosalam Jombang Regency. The research was conducted by surveys, primary and secondary data from PT. Fructi Agri Sejati were obtained through interviews and questionnaire. Business feasibility analysis based on investment feasibility criteria include Net Present Value (NPV), Net Benefit Cost Ratio (Net B/C), Internal Rate Return (IRR), Payback Period (PP) and $R / C$ Ratio for analysis production efficiency. The results of this research were showed that the average value income per year has Rp.141.669.425, and the average inflow per year of Rp.898.382.687 which was sourced from the sale of milk, calf, cow, and manure. The business in PT. Fructi Agri Sejati is feasible because all the investment criteria are achievable. PT. Fructi Agri have NPV>0 of Rp.181.016.633, Net B/C>0 of 1,15, IRR is $12,3 \%$ larger than the discount rate used and PP for 7,2 years. Production efficiency in PT. Fructi Agri Sejati is efficient because the value $R / C>0$ of 1,18 .
\end{abstract}

Key words: financial feasibility, production efficiency, PT. Fructi Agri Sejati, Jombang 


\section{PENDAHULUAN}

Peternakan sapi perah merupakan salah satu usaha di bidang peternakan yang memiliki peran strategis dalam memenuhi kebutuhan pangan yang terus meningkat, peningkatan pendapatan penduduk, dan peningkatan perekonomian nasional (Simamora dkk., 2015).

Menurut Astuti dkk. (2010) usaha sapi perah di Indonesia masih berbasis peternakan rakyat yang mempunyai struktur modal rendah. Kepemilikan sapi perah rata-rata peternak sekitar 2-4 ekor per peternak, sehingga efisiensi sulit dicapai (Mandaka dan Hotaganol, 2005). Peningkatan efisiensi usaha peternakan sapi perah menjadi satu langkah yang sangat strategis untuk dilakukan dalam rangka mendukung kemandirian pangan nasional dan peningkatan pendapatan nasional, serta dapat meningkatkan pendapatan rumah tangga peternak (Asmara dkk., 2015). Analisis kelayakan usaha menjadi masukan berguna yang mengkaji aspek finansial secara komprehensif dan detail, sehingga dapat dijadikan dasar bagi investor untuk membuat keputusan investasi secara lebih obyektif (Sofyan, 2003).

Berdasarkan data dari portal resmi Pemerintah Kabupaten Jombang (2017) PT. Fructi Agri Sejati merupakan Perseroan Terbatas dengan bidang usaha pembibitan dan budidaya sapi perah yang terdapat di Kabupaten Jombang yang menjadi salah satu usaha peternakan sapi perah skala besar. Menurut Emawati (2011) persentase dari usaha ternak sapi perah rakyat di Indonesia dengan skala besar (memiliki lebih dari tujuh ekor sapi perah) hanya sampai $3 \%$. Berkaitan dengan hal tersebut perlu dilaksanakan adanya penelitian tentang analisis kelayakan usaha secara finansial dan efisiensi produksi peternakan sapi perah PT. Fructi Agri Sejati untuk mengetahui pendapatan yang dikelola dan juga faktor produksi yang diutamakan sebagai prioritas untuk mendapatkan keuntungan.

\section{METODE PENELITIAN}

Penelitian dilaksanakan di peternakan sapi perah PT. Fructi Agri Sejati Dusun Komboh
Desa Sambirejo Kecamatan Wonosalam Kabupaten Jombang. Jenis penelitian yang digunakan dalam penelitian ini adalah jenis penelitian deskriptif, memberikan gambaran mengenai kelayakan usaha sapi perah PT. Fructi Agri Sejati melalui penilaian aspek secara finansial. Menurut Nurmalina dkk. (2014) meliputi Net Present Value (NPV), Benefict Cost Ratio (B/C), Internal Rate Return (IRR), dan Payback Period (PP) serta efisiensi produksi melalui metode analisis R/C Ratio (Santosa dkk., 2013).

Prosedur pengambilan data dilakukan melalui teknik observasi, teknik wawancara melakukan tanya jawab langsung dengan bantuan kuesioner atau daftar pertanyaan dan teknik dokumentasi (Fanani, 2010). Umur proyek yang ditetapkan selama 10 tahun, dengan tahun pertama awal proyek di tahun 2008 sampai tahun sepuluh yaitu 2017. Data-data yang sudah terkumpul dianalisis dengan menggunakan penghitungan secara matematis. Rumus-rumus yang digunakan adalah sebagai berikut (Gittinger, 1986) :

$$
\begin{aligned}
& \text { Net Present Value (NPV) } \\
& \qquad N P V=\sum_{t=1}^{n} \frac{B_{t}-C_{t}}{(1+i)^{t}}
\end{aligned}
$$

Keterangan :

Bt: Penerimaan yang diperoleh tahun ke-t (Rp)

$\mathrm{Ct}$ : Biaya yang dikeluarkan pada tahun ke-t (Rp)

$\mathrm{n}$ : Umur ekonomis proyek (tahun)

i: Tingkat suku bunga (persen)

$\mathrm{t}:(\mathrm{t}=0,1,2, \ldots \mathrm{n})$ tahun

$$
\begin{aligned}
& \text { Net Benefict Cost Ratio }(\text { Net } \mathrm{B} / \mathrm{C}) \\
& N e t B / C \text { Ratio }=\frac{\sum_{t=1}^{n} \frac{B_{t}-C_{t}}{(1+i)^{t}} \geq 0}{\sum_{t=1}^{n} \frac{B_{t}-C_{t}}{(1+i)^{t}} \leq 0}
\end{aligned}
$$

Keterangan :

Bt: Penerimaan yang diperoleh tahun ke-t ( Rp)

$\mathrm{Ct}$ : Biaya yang dikeluarkan pada tahun ke-t (Rp)

n: Umur ekonomis proyek (tahun)

i: Tingkat suku bunga (persen)

$\mathrm{t}:(\mathrm{t}=0,1,2, \ldots \mathrm{n})$ tahun 
Internal Rate Return (IRR)

$$
I R R=i_{1}+\frac{N P V_{1}}{N P V_{1}+N P V_{2}}\left(i_{2}-i_{1}\right)
$$

Keterangan :

NPV1: NPV yang bernilai positif (Rp)

NPV2: NPV yang bernilai negatif (Rp)

i1: Tingkat bunga NPV positif (persen)

i2: Tingkat bunga NPV negatif (persen)

\section{Payback Period (PP)}

$$
P=\frac{I}{A}
$$

Keterangan :

P: Jumlah waktu yang diperlukan untuk mengembalikan modal investasi (Tahun)

I: Biaya investasi (Rp)

A: Benefit bersih tiap tahun (Rupiah).

$$
\begin{gathered}
\text { Return Cost Ratio }(\mathrm{R} / \mathrm{C}) \\
\mathrm{R} / \mathrm{C} \text { Ratio }=\frac{\text { Total Revenue }(\mathrm{TR})}{\text { Total Cost }(\mathrm{TC})}
\end{gathered}
$$

\section{HASIL DAN PEMBAHASAN}

Bangsa sapi yang digunakan di PT. Fructi Agri Sejati adalah sapi Peranakan Fries Holland (PFH) berjumlah 100 ekor dengan produksi susu rata-rata sebesar 13 liter/ekor/hari dan memiliki pegawai atau tenaga kerja berjumlah 11 orang.

Unsur pokok analisis finansial adalah dengan menghitung penerimaan dan biaya-biaya yang digunakan (Gusasi dan Saade, 2006). Pengeluaran tunai untuk operasi mencakup seluruh pengeluaran tunai yang timbul untuk memproduksi output, diantaranya biaya operasional-variabel dan biaya operasional-tetap (Nurmalina dkk., 2014). Hasil penelitian di PT. Fructi Agri Sejati pada tabel 1 rata-rata penerimaan per tahun sebesar Rp.1.800.232.042 didapat dari penjualan susu, induk laktasi, induk afkir, pejantan, pedet jantan dan pupuk kandang. Biaya tetap yang dikeluarkan untuk usaha sapi perah di PT. Fructi Agri Sejati sebesar Rp.171.677.666 setiap tahunnya meliputi tagihan air, tagihan listrik, gaji karyawan, telepon, PBB, transportasi dan penyusutan. Komponen biaya variabel rata-rata sebesar Rp.375.449.200 per tahun meliputi biaya dari pakan, obat, vitamin,
Inseminasi Buatan, pelumas/vaselin dan pajak pendapatan usaha.

Modal yang berasal dari sumber intern adalah modal atau dana yang dibentuk atau dihasilkan sendiri dari dalam perusahaan (Ernawan dkk., 2016). Hasil penelitian berdasarkan tabel 2 menunjukkan modal yang digunakan di PT. Fructi Agri Sejati berasal dari sumber sendiri (intern) dengan biaya investasi sebesar Rp. 1.022.170.000 terdiri dari biaya untuk pembelian ternak, lahan, pembuatan kandang dan biaya peralatan lainnya.

Nilai rata-rata penyusutan di tabel 3 menggunakan metode straight line method (Soeyatno, 2013), nilai pendapatan penyusutan di PT. Fructi Agri Sejati sebesar Rp.25.277.666 setiap tahunnya. Rincian laporan laba rugi akan berpengaruh terhadap pajak penghasilan usaha sehingga akan berpengaruh juga pada cash flow (Soepranianondo dkk., 2013). Menurut Kasmir dan Jakfar (2008) cash flow yaitu aktivitas keuangan yang mempengaruhi posisi/kondisi kas pada suatu periode tertentu dan menjadi bagian penting yang harus diperhatikan oleh manajemen, investor, konsultan, dan stakeholder lainnya untuk memperhitungkan kelayakan berdasarkan kriteria kelayakan investasi dan digunakan untuk mengukur tingkat kelayakan usaha peternakan sapi perah yang dijalakan di PT. Fructi Agri Sejati.

Berdasarkan tabel 4 hasil penghitungan menunjukkan bahwa pendapatan rata-rata per tahun sebesar Rp.141.669.425 dengan tingkat bunga sebesar 9,75\% didapatkan nilai NPV >0 sebesar Rp.181.016.633. Usaha peternakan sapi perah menguntungkan untuk dilaksanakan jika NPV >0 karena memberi manfaat bersih atau keuntungan (Husnan dan Suwarsono, 2000). Didapatkan hasil Net B/C >0 yaitu sebesar 1,15, semakin besar nilai Net B/C maka keuntungan yang diperoleh semakin besar dan semakin layak untuk diusahakan (Utari, 2015). Hasil penelitian Hermanto (2010) menunjukkan bahwa nilai Net $\mathrm{B} / \mathrm{C}>0$ sebesar 1,21 menunjukkan pengeluaran investasi sebesar Rp.1 akan menghasilkan nilai pendapatan bersih sebesar Rp.1,21.

Hasil penghitungan IRR sebesar 12,3\%, berada di atas nilai diskonto yang ditentukan 
Tabel 1. Rata-rata komponen biaya usaha dan penerimaan di PT. Fructi Agri Sejati per tahun

\begin{tabular}{lclclc}
\hline Biaya Tetap & $\mathbf{( R p )}$ & Biaya Variabel & $(\mathbf{R p )}$ & Penerimaan & $(\mathbf{R p )}$ \\
\hline Tagihan air & 2.400 .000 & Hijauan & 45.552 .000 & Susu & 662.553 .000 \\
Tagihan & 3.600 .000 & Konsentrat & 314.768 .700 & Induk afkir & 103.900 .000 \\
listrik & & & & & \\
Gaji & 126.000 .000 & Obat-obatan & 2.708 .000 & Pedet jantan & 34.666 .666 \\
karyawan & 600.000 & Vitamin & 5.077 .500 & Pejantan & 21.000 .000 \\
Telepon & 800.000 & straw/semen & 3.696 .000 & Kompos & 79.729 .687 \\
PBB & 1.000 .000 & vaselin & 3.647 .000 & & \\
Transportasi & 37.277 .666 & & & & \\
Penyusutan & $\mathbf{1 7 1 . 6 7 7 . 6 6 6}$ & Total & $\mathbf{3 7 5 . 4 4 9 . 2 0 0}$ & Total & $\mathbf{1 . 8 0 0 . 2 3 2 . 0 4 2}$ \\
\hline Total & \multicolumn{5}{c}{}
\end{tabular}

Tabel 2. Biaya investasi di PT. Fructi Agri Sejati

\begin{tabular}{llccrr}
\hline No. & Komponen Biaya & Satuan & Jumlah & Harga Satuan (Rp) & Jumlah Biaya (Rp) \\
\hline 1 & Lahan & meter & 2.700 & 200.000 & 510.000 .000 \\
2 & Kandang & unit & 1 & 240.000 .000 & 240.000 .000 \\
2 & Pedet & ekor & 3 & 8.000 .000 & 24.000 .000 \\
3 & Sapi dara & ekor & 6 & 14.000 .000 & 48.000 .000 \\
4 & Sapi laktasi pertama & ekor & 5 & 17.000 .000 & 85.000 .000 \\
5 & Mobil pick up & unit & 1 & 90.000 .000 & 90.000 .000 \\
6 & Chopper & unit & 1 & 10.000 .000 & 10.000 .000 \\
7 & Timbangan & unit & 1 & 7.000 .000 & 7.000 .000 \\
8 & Gerobak & unit & 10 & 500.000 & 5.000 .000 \\
9 & Sekop & unit & 5 & 200.000 & 1.000 .000 \\
10 & Milk can & unit & 9 & 56.000 & 500.000 \\
11 & Tong & unit & 25 & 13.200 & 330.000 \\
12 & Selang & unit & 2 & 300.000 & 600.000 \\
13 & Sepatu boot & pasang & 7 & 50.000 & 350.000 \\
14 & Sikat & unit & 4 & 5.000 & 20.000 \\
15 & Sapu lidi & unit & 5 & 20.000 & 100.000 \\
16 & Gayung & unit & 4 & 5.000 & 20.000 \\
17 & Peralatan medis & unit & 1 & 250.000 & 250.000 \\
\hline Total biaya investasi di PT. Fructi Agri Sejati & & & 1.022 .170 .000 \\
\hline
\end{tabular}

Tabel 3. Nilai penyusutan usaha peternakan sapi perah di PT. Fructi Agri Sejati

\begin{tabular}{clrrr}
\hline No. & Komponen Biaya & Nilai Beli (Rp) & Umur Ekonomis (Tahun) & Penyusutan per Tahun (Rp) \\
\hline 1 & Lahan & 540.000 .000 & & 1.000 .000 \\
2 & Kandang & 260.000 .000 & 20 & 13.000 .000 \\
3 & Mobil pick up & 90.000 .000 & 10 & 10.000 .000 \\
4 & Chopper & 10.000 .000 & 15 & 6.666 .667 \\
5 & Timbangan & 7.000 .000 & 10 & 350.000 \\
6 & Gerobak & 5.000 .000 & 5 & 1.000 .000 \\
7 & Sekop & 1.000 .000 & 5 & 200.000 \\
8 & Milk can & 500.000 & 10 & 25.000 \\
9 & Tong & 330.000 & 5 & 16.500 \\
\hline
\end{tabular}




\begin{tabular}{|c|c|c|c|}
\hline 10 Selang & 600.000 & 2 & 300.000 \\
\hline 11 Sepatu boot & 350.000 & 2 & 175.000 \\
\hline 12 Sikat & 20.000 & 2 & 10.000 \\
\hline 13 Sapu lidi & 100.000 & 2 & 50.000 \\
\hline 14 Gayung & 20.000 & 2 & 10.000 \\
\hline 15 Peralatan medis & 250.000 & 5 & 50.000 \\
\hline
\end{tabular}

Total Nilai Penyusutan

25.277.666

Tabel 4. Hasil analisis finansial dan efisiensi produksi di PT. Fructi Agri Sejati (Rp)

\begin{tabular}{lrrrrr}
\hline Tahun Ke- & \multicolumn{1}{c}{ Inflow } & \multicolumn{1}{c}{ Outflow } & \multicolumn{1}{c}{ Net Benefit } & \multicolumn{1}{c}{ DF 9,75 \% } & \multicolumn{1}{c}{ PV Income } \\
\hline $1(2008)$ & 115.689 .375 & 1.230 .146 .000 & -1.114 .456 .625 & 0,911161731 & -1.015 .450 .228 \\
$2(2009)$ & 287.930 .625 & 291.327 .614 & -3.396 .989 & 0,8302157 & -2.820 .233 \\
$3(2010)$ & 481.016 .875 & 631.227 .052 & -150.210 .177 & 0,756460775 & -113.628 .106 \\
$4(2011)$ & 658.728 .750 & 536.167 .146 & 122.561 .604 & 0,689258109 & 84.476 .579 \\
$5(2012)$ & 880.471 .875 & 638.843 .427 & 241.628 .448 & 0,628025612 & 151.748 .853 \\
$6(2013)$ & 1.060 .974 .375 & 806.716 .302 & 254.258 .073 & 0,572232904 & 145.494 .835 \\
$7(2014)$ & 1.172 .453 .750 & 834.000 .271 & 338.453 .479 & 0,521396723 & 176.468 .535 \\
$8(2015)$ & 1.522 .511 .250 & 893.366 .521 & 629.144 .729 & 0,475076741 & 298.892 .027 \\
$9(2016)$ & 1.443 .700 .625 & 859.007 .615 & 584.693 .010 & 0,432871746 & 253.097 .084 \\
$10(2017)$ & 1.360 .349 .375 & 846.330 .677 & 514.018 .698 & 0,394416169 & 202.737 .285 \\
\hline Manfaat per tahun & & & & 141.669 .425 \\
NPV > 0 & & & & & 181.016 .633 \\
Net B/C > 0 & & & & & 1,15 \\
IRR > DF & & & & & $12,3 \%$ \\
PP > 10 Tahun & & & & & 7,2 \\
R/C > 1 & & & & & \\
\hline
\end{tabular}

yaitu $9,75 \%$. Hasil penelitian Nasution (2016) diperoleh nilai IRR sebesar $15 \%$, berada di atas nilai diskonto yang digunakan yaitu sebesar $11,5 \%$ jika IRR $>$ Opportunity Cost of Capital atau Discount Rate maka bisnis layak untuk dilaksanakan. Payback Period atau PP diperoleh nilai sebesar 7,2 kurang dari umur proyek yaitu 10 tahun. Nasution (2016) titik pengembalian investasi pada saat kegiatan usaha selama 9.63 tahun. Pengembalian investasi kurang dari umur proyek yang ditetapkan yaitu 10 tahun, berdasarkan kriteria kelayakan investasi menunjukkan usaha layak untuk dijalankan. Semakin pendek waktu yang dibutuhkan untuk mengembalikan nilai investasi yang dikeluarkan maka bisnis semakin layak diusahakan nilai (Subagyo, 2007).

Nilai R/C usaha peternakan sapi perah di PT. Fructi Agri Sejati yaitu 1,18 yang terdapat di tabel 4. Berdasarkan hasil analisis R/C Ernawan dkk. (2016) menunjukkan bahwa usaha peternakan layak diusahakan karena nilai $\mathrm{R} / \mathrm{C}$ sebesar 1,054>1. Nilai R/C 1,054 artinya bahwa setiap Rp.1.000 biaya yang dikeluarkan akan menghasilkan penerimaan sebesar Rp.1.054. Semakin besar nilai R/C maka penerimaan yang diperoleh semakin besar dan usaha tersebut semakin layak untuk diusahakan (Halolo, 2013).

\section{KESIMPULAN}

Analisis kelayakan usaha secara finansial di peternakan sapi perah PT. Fructi Agri Sejati layak untuk dijalankan karena semua kriteria investasi meliputi Net Present Value (NPV), Benefict Cost Ratio (B/C), Internal Rate Return (IRR), dan Payback Period (PP) mampu dicapai. Efisiensi usaha di PT. Fructi Agri Sejati juga dinyatakan sudah efisien karena nilai hasil penelitian menunjukkan nilai $\mathrm{R} / \mathrm{C}>1$. 


\section{UCAPAN TERIMA KASIH}

Peneliti mengucapkan terima kasih untuk Bapak Patrick George Peeters atas izin yang diberikan untuk melaksanakan penelitian dan para tenaga kerja atas bantuan yang telah diberikan.

\section{DAFTAR PUSTAKA}

Asmara, A., L.P. Yeti dan D. Lubis. 2015. Keragaan Produksi Susu dan Efisiensi Usaha Peternakan Sapi Perah Rakyat Indonesia. Bogor. P-ISSN: 1693-5853 E-ISSN: 24072524.

Astuti M., R. Widiati, dan Y.S. Yustina. 2010. Efisiensi Produksi Usaha Sapi Perah Rakyat (Studi Kasus pada Peternak Anggota Koperasi Usaha Peternakan dan Pemerahan Sapi Perah Kaliurang, Sleman, Yogyakarta). Jurnal Buletin Peternakan, 34(1): 64-69.

Fanani, Z. 2010. Analisis Faktor-Faktor Penentu Persistensi Laba. Jurnal Akuntansi dan Keuangan Indonesia, 7(1): 109-123.

Gusasi, A. dan M. A. Saade. 2006. Analisis Pendapatan dan Efisiensi Usaha Ternak Ayam Potong pada Skala Usaha Kecil. Jurnal Agrisistem.

Emawati, S. 2011. Profitabilitas Usahatani Sapi Perah Rakyat di Kabupaten Sleman. Jurnal Science Peternakan, 9(2): 100-108.

Ernawan, M., E. Trijana dan R. Ghozali. 2016. Analisis Pendapatan Usaha Peternakan Sapi Perah Laktasi (Studi Kasus di Desa Minggirsari Kecamatan Kanigoro Kabupaten Blitar). Jurnal Aves, 10(2).

Gittinger. 1986. Analisis Ekonomi ProyekProyek Pertanian. Jakarta. UI Press.
Halolo, R.D., S.I. Santoso dan S. Marzuki. 2013. Efisiensi Usaha Peternakan Sapi Perah di Kabupaten Semarang. Agromedia, 31: 1-8.

Hermanto, B.T. 2010. Analisis Kelayakan Usaha Sapi Perah Kelompok Ternak Baru Sireum di Desa Cibeureum, Kecamatan Cisarua, Kabupaten Bogor [Skripsi]. Institut Pertanian Bogor.

Husnan, S. dan Suwarsono. 2000. Studi Kelayakan Proyek. Yogyakarta. Unit Penerbit dan Pencetak AMP YKPN.

Kasmir dan Jakfar. 2008. Studi Kelayakan Bisnis. Jakarta. Kencana Prenada Media Group.

Mandaka, S. dan M.P. Hutagaol. 2005. Analisis Fungsi Keuntungan, Efisiensi Ekonomi dan Kemungkinan Skema Kredit bagi Pengembangan Skala Usaha Peternakan Sapi Perah Rakyat di Kelurahan Kebon Pedes, Kota Bogor. Jurnal Agro Ekonomi, 23: 191208.

Nasution, A.G. 2016. Analisis Kelayakan Usaha Peternakan Sapi Perah di Kawasan Usaha Peternakan (Kunak) Kabupaten Bogor [Skripsi]. Fakultas Ekonomi dan Manajemen. Institut Pertanian Bogor.

Nurmalina, R., T. Sarianti dan A. Karyadi. 2014. Studi Kelayakan Bisnis. Bogor. Institut Pertanian Bogor.

Portal Resmi Pemerintah Kabupaten Jombang. 2017. Peta Kecamatan Wonosalam. http:/jombangkab.go.id. [20 November 2017].

Simamora, T., A.M. Fuah., A. Atabany dan Burhanuddin. 2015. Evaluasi Aspek Teknis Peternakan Sapi Perah Rakyat di Kabupaten Karo Sumatera Utara. Jurnal Ilmu Produksi dan Teknologi Hasil Peternakan, 03(1): 5258 . 
Rahayu, E. T. 2013. Analisis Pendapatan Usaha Ternak Sapi Perah di Kecamatan Cepogo Kabupaten Boyolali. Jurnal Sains Peternakan, 11(2): 99-105.

Santosa, S. I., S. Agus dan W. Ratih. 2013. Analisis Potensi Pengembangan Usaha Peternakan Sapi Perah dengan Menggunakan Paradigma Agribisnis di Kecamatan Musuk Kabupaten Boyolali. Buletin Peternakan, 37(2): 125-135.

Soepranianondo, K., R. Sidik, D. S. Nazar, S. Hidanah, Prastisto dan S. H. Warsito. 2013. Buku Ajar Kewirausahaan. Airlangga University Press. Surabaya. Hal.191-207.
Soeyatno, R.F. 2013. Analisis Pendapatan dan Faktor-faktor yang Mempengaruhi Produksi Susu di Desa Pendesari Kecamatan Pujon Kabupaten Malang Jawa Timur [Thesis]. Institut Pertanian Bogor.

Sofyan, I. 2003. Studi Kelayakan Bisnis. Yogyakarta. Graha Ilmu.

Subagyo, A. 2007. Studi Kelayakan : Teori dan Aplikasi. Jakarta. Elex Media Komputindo.

Utari, A.R.T. 2015. Analisis Kelayakan Usaha Ternak Sapi Potong pada Berbagai Skala Kepemilikan di Desa Samangki Kecamatan Simbang Kabupaten Maros [Skripsi]. Fakultas Peternakan. Universitas Hasanuddin. 